\title{
Proteomic response of Trichoderma aggressivum f. europaeum to Agaricus bisporus tissue and mushroom compost
}

\author{
Matt O’BRIEN ${ }^{a, b}$, Helen GROGAN ${ }^{b}$, Kevin KAVANAGH ${ }^{a, *}$ \\ ${ }^{a}$ Department of Biology, National University of Ireland Maynooth, Co. Kildare, Ireland \\ ${ }^{\mathrm{b}}$ Mushroom Research Group, Crops, Environment and Land Use Programme, Teagasc, Ashtown, Dublin 15, Ireland
}

\section{A R T I C L E I N F O}

Article history:

Received 12 February 2014

Received in revised form

11 June 2014

Accepted 23 June 2014

Available online 8 July 2014

Corresponding Editor:

Daniel Eastwood

Keywords:

Fungal pathogen

Mushroom production

Mycoparasite

Stress tolerance

Virulence

\begin{abstract}
A B S T R A C T
A cellular proteomic analysis was performed on Trichoderma aggressivum f. europaeum. Thirty-four individual protein spots were excised from 2-D electropherograms and analysed by ESI-Trap Liquid Chromatography Mass Spectrometry (LC/MS). Searches of the NCBInr and SwissProt protein databases identified functions for 31 of these proteins based on sequence homology. A differential expression study was performed on the intracellular fraction of T. aggressivum f. europaeum grown in media containing Agaricus bisporus tissue and Phase 3 mushroom compost compared to a control medium. Differential expression was observed for seven proteins, three of which were upregulated in both treatments, two were down regulated in both treatments and two showed qualitatively different regulation under the two treatments. No proteins directly relating to fungal cell wall degradation or other mycoparasitic activity were observed. Functions of differentially produced intracellular proteins included oxidative stress tolerance, cytoskeletal structure, and cell longevity. Differential production of these proteins may contribute to the growth of T. aggressiuum in mushroom compost and its virulence toward A. bisporus.
\end{abstract}

(c) 2014 The British Mycological Society. Published by Elsevier Ltd. All rights reserved.

\section{Introduction}

Trichoderma aggressivum is a filamentous fungus which causes severe economic losses in the cultivation of the edible mushroom Agaricus bisporus (Seaby 1987; Samuels et al. 2002; Mamoun et al. 200b). It was first isolated in Ireland in the late 1980s and has since been reported across Europe and North America (Muthumeenakshi et al. 1994; Fuente et al. 1998; Hermosa et al. 1999; Mamoun et al. 2000a; Kredics et al. 2010; Sobieralski et al. 2010). There are two subspecies, T. aggressivum f. aggressivum and T. aggressivum f. europaeum found in North America and Europe, respectively (Samuels et al. 2002)

Trichoderma aggressivum colonises the compost used as a growth substrate in mushroom cultivation (Largeteau \& Savoie 2010). In later stages of colonisation green coloured conidia form in both the compost and the casing layer of infected areas which gives the condition its common names, green mould disease or Trichoderma compost mould (Seaby 1987; Fletcher \& Gaze 2008). In areas colonised by T. aggressivum mushroom fruit body formation is retarded and fruit bodies that do form may be of poor quality due to damage or

\footnotetext{
* Corresponding author. Department of Biology, NUI Maynooth, Co. Kildare, Ireland. Tel.: +353 1708 3859; fax: +353 17083845 .

E-mail address: kevin.kavanagh@nuim.ie (K. Kavanagh).

http://dx.doi.org/10.1016/j.funbio.2014.06.004

1878-6146/@ 2014 The British Mycological Society. Published by Elsevier Ltd. All rights reserved.
} 
discolouration (Largeteau \& Savoie 2010). The estimated losses in mushroom yield caused by T. aggressivum worldwide are in the tens of millions of dollars (Kredics et al. 2010).

The mechanisms of $\mathrm{T}$. aggressivum colonisation of mushroom compost are not fully understood but it is thought to involve both mycoparasitic and saprotrophic components (Williams et al. 2003). Trichoderma aggressivum can colonise mushroom compost in the presence or absence of $A$. bisporus, but it sporulates more heavily when $A$. bisporus is present (Largeteau \& Savoie 2010). Its growth is inhibited by compost microbiota, but less so than other Trichoderma species (Savoie et al. 2001a).

The tolerance of T. aggressivum to the presence of compost microbiota and A. bisporus and its ability to acquire nutrition from the mushroom compost and mushroom spawn have been proposed as the attributes that make it so harmful to mushroom agriculture (Savoie et al. 2001a; Williams et al. 2003; Fletcher \& Gaze 2008). Trichoderma aggressivum is known to produce metabolites which are toxic to A. bisporus (Mumpuni et al. 1998; Krupke et al. 2003; Guthrie \& Castle 2006), but other Trichoderma species, which do not cause severe green mould disease, are known to produce metabolites which may be as toxic (Mumpuni et al. 1998).

In this study, proteomic analysis was employed to study the response of T. aggressivum f. europaeum to mushroom compost and A. bisporus tissue in vitro. Previous studies (Savoie et al. 2001b; Williams et al. 2003; Guthrie \& Castle 2006) have described the importance of proteins secreted by T. aggressivum (prev. Trichoderma harzianum) in its interaction with A. bisporus, however there is little information published on the intracellular protein fraction of T. aggressivum, which is the focus of this study.

\section{Materials and methods}

\section{Culture conditions}

Stocks of Trichoderma aggressivum f. europaeum strain CBS 100526 were retrieved from liquid nitrogen storage and cultured for $2 \mathrm{~d}$ on malt extract agar (Fluka) at $25^{\circ} \mathrm{C}$ in the dark. Plugs $(5 \mathrm{~mm}$ ) were excised from the growing edge of a culture and inoculated into liquid media $(100 \mathrm{ml}$ volume in a $250 \mathrm{ml}$ conical flask) and incubated at $20{ }^{\circ} \mathrm{C}$ on an orbital shaker at $100 \mathrm{rpm}$ in the dark. For proteome analysis the medium consisted of $2 \%(\mathrm{w} / \mathrm{v})$ malt extract (Fluka) and incubation was carried out for $3 \mathrm{~d}$ until hyphal mass was $4-5 \mathrm{~g}$ wet weight. For differential protein analysis three treatments were prepared: treatment 1 consisted of $1 \%(\mathrm{w} / \mathrm{v})$ malt extract with $1 \% \mathrm{w} / \mathrm{v}$ mushroom cap tissue added prior to autoclave sterilisation, treatment 2 consisted of $1 \%(\mathrm{w} / \mathrm{v})$ malt extract with $1 \%(\mathrm{w} /$ v) lyophilised Phase 3 mushroom compost added prior to autoclave sterilisation, the control treatment consisted of $1 \%$ malt extract only. Mushroom cap tissue was obtained from the commercial Agaricus bisporus strain Sylvan A15 harvested prior to opening, several fruit bodies were finely chopped and a random sample of fresh cap tissue was removed. Phase 3 compost was obtained by inoculating Phase 2 mushroom compost with Sylvan A15 spawn and incubating under standard industrial spawn-run conditions until A. bisporus colonisation was complete, compost was lyophilised for storage, and rehydrated in culture medium prior to autoclaving. Cultures for differential protein analysis were incubated for a total of $7 \mathrm{~d}$ and wet weights of 3-4 g hyphae were attained. Malt extract was used as the base medium to ensure a consistent level of hyphal growth and adequate protein yields and because growth on more minimal media causes the induction of mycoparasitism related genes in Trichoderma species due to starvation (Viterbo et al. 2002).

\section{Protein extraction}

After the incubation period the whole mycelial mass was filtered through a double layer of autoclaved Miracloth and washed twice with sterile water to remove residual culture medium. Cells were lysed by grinding in liquid nitrogen and the lysate resuspended in homogenisation buffer $(0.4 \mathrm{M}$ $\mathrm{NaCl}, 10 \mathrm{mM}$ tris- $\mathrm{HCl}, 2 \mathrm{mM}$ Ethylenediaminetetraacetic Acid (EDTA), $10 \mu \mathrm{g}$ pepstatin A ml ${ }^{-1}$, Tosyllysine Chloromethyl Ketone (TLCK), leupeptin and aprotinin, pH 8.0). Resuspended lysate was transferred to $1.5 \mathrm{ml}$ Eppendorf tubes and centrifuged at $1000 \mathrm{rcf}$ at $4^{\circ} \mathrm{C}$ for $5 \mathrm{~min}$. The supernatant containing cellular protein was removed to a fresh Eppendorf tube and the pellet discarded. Protein concentration was determined with the Biorad Bradford assay kit using a Biophotometer spectrophotometer (Eppendorf) calibrated at a range of 100-1500 mg ml ${ }^{-1}$ against BSA standards (Bradford, 1976). Protein samples $(350 \mathrm{mg}$ ) were acetone precipitated, concentrated by centrifugation, and resuspended in $250 \mathrm{ml}$ isoelectric focussing (IEF) buffer (8 M urea, $1 \%$ triton X100, $4 \%$ 3[(3-Chloamidopropyl) dimethy (ammanio)] Propanesulfonate (CHAPS), $10 \mathrm{mM}$ tris-HCl, $2 \mathrm{M}$ thiourea, $65 \mathrm{mM}$ Diothiothreitol (DTT), and $\sim 0.01 \mathrm{~g}$ bromophenol blue). Protein for differential analysis was prepared from two biological replicates per treatment and pooled within each treatment prior to IEF.

\section{IEF and 2-D PAGE}

IEF was carried out using $13 \mathrm{~cm}$ Immobiline Drystrip pH 4-7 gradient strips (GE Healthcare) in a coffin system Ettan IPGPhor II (Amersham bioscience). Samples were added directly to the strip by active rehydration followed by IEF. Rehydration focussing protocol was as follows: $50 \mathrm{~V}$ for $10 \mathrm{~h}, 0.25 \mathrm{~V}$ for $30 \mathrm{~min}, 8000 \mathrm{~V}$ gradient for $5 \mathrm{~h}, 8000 \mathrm{~V}$ for $8 \mathrm{~h}$. After focussing, strips were equilibrated for $10 \mathrm{~min}$ in reducing buffer $(30 \%$ glycerol, $2 \%$ SDS, $6 \mathrm{M}$ urea, $50 \mathrm{mM}$ tris-HCl, $1 \% \mathrm{DTT}, \mathrm{pH}$ 6.8) followed by $10 \mathrm{~min}$ in alkylating buffer (30\% glycerol, $2 \% \mathrm{SDS}, 6 \mathrm{M}$ urea, $50 \mathrm{mM}$ tris- $\mathrm{HCl}, 12.5 \%$ Indole acetic acid (IAA), $\mathrm{pH}$ 6.8).

Isoelectrically focussed proteins were resolved using Sodium dodecyl sulfate-Polyacrylamide gel electrophoresis (SDS-PAGE). Slab gels (12.5\%) were cast at $1.5 \mathrm{~cm}$ thickness in a Biorad Protean II multi-gel casting chamber. Focused and equilibrated IEF Drystrips were laid on top of the gel and sealed with agarose sealing solution (1\% agarose, $0.1 \%$ bromophenol blue in $1 \times$ gel running buffer). Gels were run in triplicate for $18 \mathrm{~h}$ at a constant wattage of $1.5 \mathrm{~W}$ per gel in a Biorad Protean Plus Dodeca-Cell using system using $1 \times$ gel running buffer (190 $\mathrm{mM}$ tris- $\mathrm{HCl}, 0.19 \mathrm{M}$ glycine, $0.1 \% \mathrm{SDS}$ ) at $10^{\circ} \mathrm{C}$. 


\section{Protein visualisation and relative quantification}

Proteins were visualised using the colloidal Coomassie staining method (Neuhoff et al. 1988; Candiano et al. 2004). Each gel was incubated in fixing solution $(50 \%(\mathrm{v} / \mathrm{v})$ ethanol, $3 \%$ (v/v) phosphoric acid) for $3 \mathrm{~h}$ on an orbital shaker, washed three times in distilled-deionised water and transferred to pre-incubation buffer (34\% (v/v) ethanol, $17 \%$ (w/v) ammonium sulphate, $3 \%$ phosphoric acid) for $20 \mathrm{~min}$ on an orbital shaker. Coomassie Brilliant blue G-250 (Serva) was added

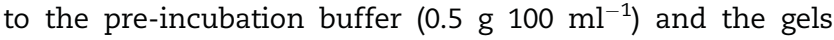
were stained at room temperature on an orbital shaker for $7 \mathrm{~d}$. Gels were destained by transferring to a new container and washing with distilled-deionised water until no stain remained.

Gels were scanned as transparencies using an Epson ImageScanner III (Epson (UK) ltd., Hertfordshire, UK) as 16 bit greyscale images with a resolution of $600 \mathrm{dpi}$. For simple protein identification spots were selected across the $\mathrm{pH}$ and weight range based on good separation and resolution. For analysis of differential proteins Progenesis Samespots software version 3.3 (Nonlinear Dynamics) was used. Gels images were normalised, analysed by two-way analysis of variance (ANOVA) and protein spots which changed in intensity at the $P<0.05$ level were selected and identified by Liquid Chromatography Mass Spectrometry (LC/MS).

\section{Protein identification by LC/MS}

Stained protein spots were excised and trypsin digested in gel as described in Shevchenko et al. (2006). Resuspended peptides were separated using an Agilent 1200 series nanoflow liquid chromatograph and analysed with an Agilent 6340 series ion trap mass spectrometer. Capillary voltage was set to $1800 \mathrm{~V}$ with a constant capillary flow rate of $2 \mu \mathrm{l} \mathrm{min}{ }^{-1}$. The mobile phase consisted of water and $90 \%$ acetonitrile both containing $0.1 \%(\mathrm{v} / \mathrm{v})$ formic acid. Sample injection size was $5 \mu \mathrm{l}$.

Compounds were generated using the Agilent software and homologies were identified using the Mascot search function of Matrix Science (www.matrixscience.com) under the following parameters: trypsin enzyme, up to two missed cleavages, fixed carboxymethyl (C) modification, variable oxidation (M) modification, 2 Da peptide tolerance, 1 Da MS/MS tolerance, $1+2+3+$ peptide charge, precursor $\mathrm{m} / \mathrm{z} \mathrm{n} / \mathrm{a}$, and ESI-TRAP instrument. Searches were carried out against all Fungi in the SwissProt and NCBInr Databases and protein matches with Mascot scores of $>46$ or $>59$ were taken to exhibit significant homology for each database, respectively. Functions were assigned to proteins based on sequence similarity using the UniProt database.

\section{Results}

\section{Analysis of Trichoderma aggressivum proteome}

LC/MS analysis allowed the identification of homologues for $27 \mathrm{~T}$. aggressivum proteins. The position of each protein spot which was excised and analysed is indicated in Fig 1 . The UniProt protein accession number, Mascot score, coverage and

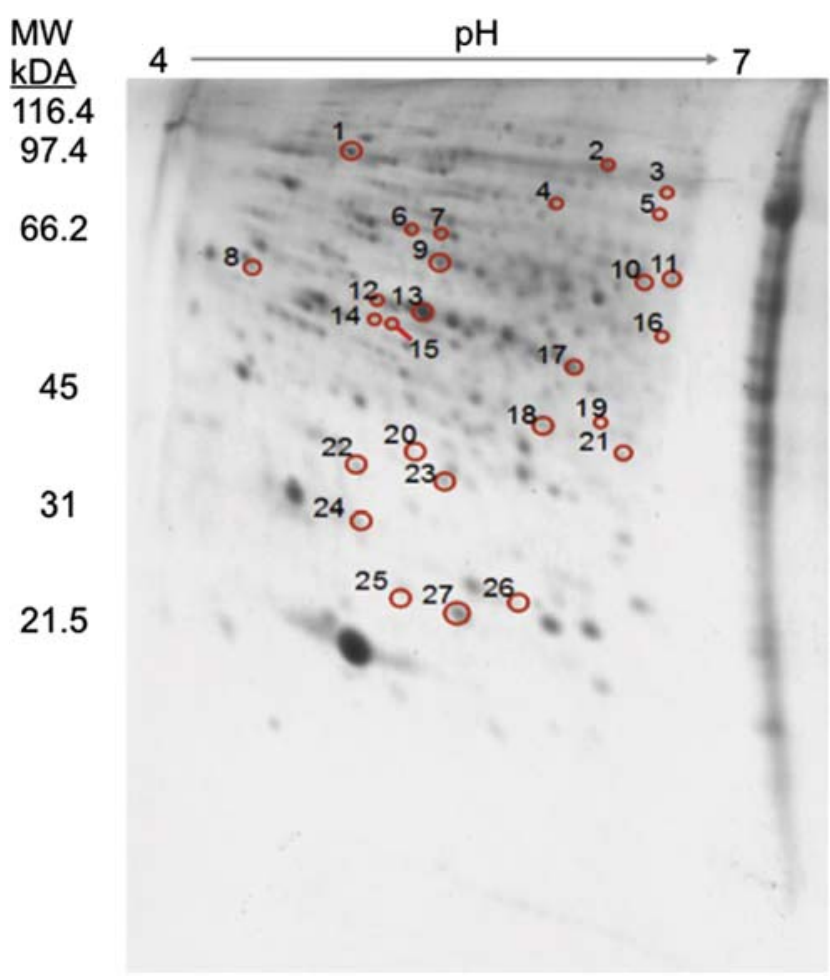

Fig 1 - Intracellular protein from T. aggressivum grown on $2 \%$ malt extract, and stained with colloidal Coomassie. Proteins analysed by LC/MS are labelled 1-27 and described in Table 1.

assigned functions for each protein returned from searches of the NCBInr protein database are shown in Table 1 . The majority of proteins were matched to the Trichoderma virens, Trichoderma reesei, or Trichoderma harzianum genomic databases (Martinez et al. 2008; Kubicek et al. 2011) with others coming from less closely related fungal species.

\section{Analysis of proteomic response of Trichoderma aggressivum to Agaricus bisporus tissue and Phase 3 mushroom compost}

Seven proteins were identified which showed a statistically significant $(P<0.05)$ change in abundance in either the mushroom compost or A. bisporus tissue treatment or both, relative to the control. The position from which each of these proteins was excised from the 2-D gel is shown in Fig 2, labelled spots A-G. The relative intensity of each spot and results returned from LC/MS analysis and Mascot search for each protein is given in Table 2.

\section{Discussion}

Trichoderma aggressivum is unique among Trichoderma species in terms of the damage it causes in the cultivation of Agaricus bisporus. This study is the first 2-D proteomic study on $T$. aggressivum and the first to assess the impact of A. bisporus tissue and mushroom compost on intracellular protein abundance in T. aggressivum. In this study 34 protein homologues 
Table 1 - Mascot search results for LC/MS analysed intracellular proteins from T. aggressivum grown on malt extract. Spot number refers to gel position indicated in Fig 1.

\begin{tabular}{|c|c|c|c|c|c|}
\hline Spot label & UniProt accession & Protein function & Species & Mascot score & Coverage $\%$ \\
\hline 1 & G9NAQ0 & Aldehyde dehydrogenase & Trichoderma virens & 122 & 12 \\
\hline 2 & A3LYZ4 & Lysophospholipase NTE1 & Scheffersomyces stipitis & 71 & 2 \\
\hline 3 & G9N9F6 & Transketolase & Trichoderma virens & 72 & 3 \\
\hline 4 & G9N370 & Glucose-methyl-choline oxido reductase & Trichoderma virens & 598 & 22 \\
\hline 5 & GORFA6 & Dehydratase & Trichoderma reesei & 352 & 19 \\
\hline 6 & E9DS21 & Aldehyde dehydrogenase & Metarhizium acridum & 97 & 7 \\
\hline 7 & G9MTN9 & Rab GDP-dissociation inhibitor & Trichoderma virens & 636 & 41 \\
\hline 8 & G9N455 & Translation elongation factor & Trichoderma virens & 216 & 28 \\
\hline 9 & D6C5B7 & Actin & Cleistogenes songorica & 676 & 46 \\
\hline 10 & G9MVH9 & $\begin{array}{l}\text { 6-phosphogluconate dehydrogenase } \\
\text { (decarboxylating) }\end{array}$ & Trichoderma virens & 370 & 16 \\
\hline 11 & G9NAQ0 & Aldehyde dehydrogenase & Trichoderma virens & 943 & 48 \\
\hline 12 & GORNE6 & Thiolase & Trichoderma reesei & 357 & 29 \\
\hline 13 & F0XBV7 & Pyruvate dehydrogenase e1 subunit & Grosmannia clavigera & 178 & 9 \\
\hline 14 & G9MRQ8 & Uncharacterised & Trichoderma virens & 518 & 29 \\
\hline 15 & G9NAQ0 & Aldehyde dehydrogenase & Trichoderma virens & 206 & 10 \\
\hline 16 & G9NMQ9 & Norsolorinic acid reductase & Trichoderma atroviride & 154 & 7 \\
\hline 17 & G9MU97 & Methyltransferase & Trichoderma virens & 98 & 3 \\
\hline 18 & A1D8L8 & Secretory lipase & Aspergillus fischerianus & 60 & 4 \\
\hline 19 & Q00640 & $\begin{array}{l}\text { Glyceraldehyde-3-phosphate } \\
\text { dehydrogenase }\end{array}$ & Erysiphe graminis & 115 & 6 \\
\hline 20 & G9N428 & $\begin{array}{l}\text { Proteasome subunit alpha type } \\
\text { decarboxylating }\end{array}$ & Trichoderma virens & 415 & 41 \\
\hline 21 & G9MEX6 & Glycolysis & Trichoderma virens & 99 & 2 \\
\hline 22 & Q6FS57 & Uncharacterised & Torulopsis glabrata & 61 & 3 \\
\hline 23 & G9N2A8 & Transcription regulation factor & Trichoderma virens & 151 & 18 \\
\hline 24 & G9MQT2 & Oxidoreductase & Trichoderma virens & 114 & 18 \\
\hline 25 & EOYRV9 & Hex1 & Trichoderma harzianum & 623 & 57 \\
\hline 26 & GORALO & Uncharacterised & Trichoderma reesei & 219 & 39 \\
\hline 27 & G0R881 & Uncharacterised & Trichoderma reesei & 132 & 17 \\
\hline
\end{tabular}

were identified for T. aggressivum proteins (Figs 1 and 2), 31 of them with known or inferred functions (see Tables 1 and 2). These homologues were drawn from a wide range of species, most commonly from the genus Trichoderma. The identified proteins can be divided into metabolic, informational, structural, and stress response functions.
Metabolic proteins are involved in the uptake of nutrients and the production of energy and the majority of proteins identified in this study were from this category. Of the analysed proteins 11 had functions relating to the degradation or modification of proteins (no. 5, 6, 12, 20), carbohydrates (no. 4,13 ), and lipids (no. 2, 18) or the glycolytic pathway (no.

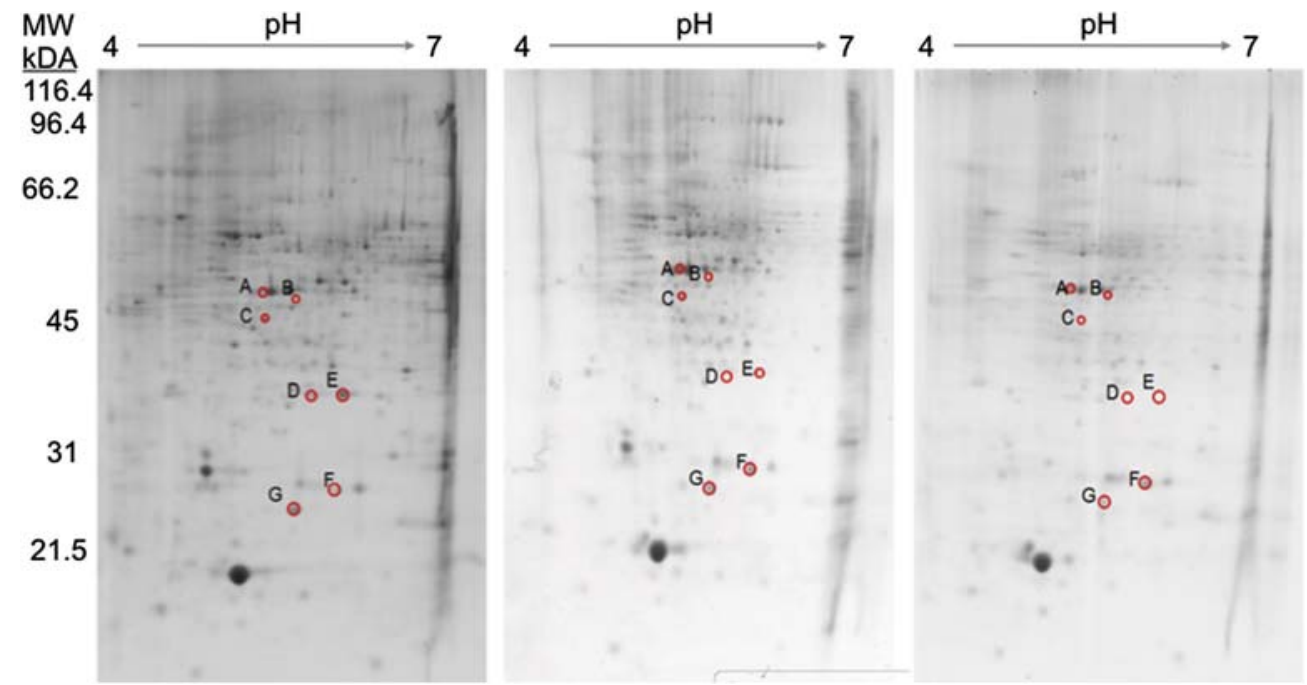

Fig 2 - Trichoderma aggressivum protein spots showing significant differential expression in media containing mushroom compost and/or A. bisporus tissue based on Progenesis Samespots analysis. From left to right the treatments are control, A. bisporus tissue and mushroom compost. LC/MS and densitometry results for each spot are given in Table 2. 
Table 2 - Mascot search results for LC/MS analysed T. aggressivum proteins showing differential expression in media containing A. bisporus tissue or Phase 3 mushroom compost. Letters refer to spot position given in Fig 2 and fold changes are expressed relative to the control treatment.

\begin{tabular}{|c|c|c|c|c|c|c|c|}
\hline Spot label & $\begin{array}{l}\text { Accession } \\
\text { number }\end{array}$ & Protein function & Species & $\begin{array}{l}\text { Mascot } \\
\text { score }\end{array}$ & \% Coverage & $\begin{array}{l}\text { Expression - } \\
\text { tissue }\end{array}$ & $\begin{array}{l}\text { Expression - } \\
\text { compost }\end{array}$ \\
\hline A & G9ND76 & $60 \mathrm{~S}$ acidic ribosomal protein & Trichoderma viride & 242 & 27 & 1.91 & 1.76 \\
\hline B & G9N1G1 & Superoxide dismutase (Fe-Mn) & Trichoderma viride & 146 & 17 & 1.15 & 2.89 \\
\hline C & G9N9E1 & Spermine/spermidine synthase & Trichoderma viride & 157 & 15 & -1.31 & -1.58 \\
\hline D & C5E1C0 & $\begin{array}{l}\text { Maintenance of telomere } \\
\text { capping protein } 2\end{array}$ & $\begin{array}{l}\text { Zygosaccharomyces } \\
\text { rouxii }\end{array}$ & 64 & 5 & -1.93 & -1.82 \\
\hline E & F0X7L2 & Guanylate kinase & Grosmannia clavigera & 80 & 5 & 2.05 & -2.03 \\
\hline $\mathrm{F}$ & A8BA83 & Superoxide dismutase $[\mathrm{Cu}-\mathrm{Zn}]$ & $\begin{array}{l}\text { Trichoderma } \\
\text { harzianum }\end{array}$ & 478 & 75 & 1.93 & 3.04 \\
\hline G & G0R881 & Actin depolymerase & Trichoderma reesei & 132 & 17 & 1.62 & 2.29 \\
\hline
\end{tabular}

10, 19, 21) while six were identified as transferases (no. 3, 17) and aldehyde dehydrogenases (no. 1, 6, 11, 15) with unknown catalytic activity (Table 1). Specific proteins involved in the degradation of pentose sugars (no. 10,13) may be relevant to the degradation of carbohydrates liberated during degradation of fibrous components of mushroom compost, however there was no significant change to these proteins in either experimental treatment (Table 2).

No proteins directly involved in the degradation of fungal cell wall components were identified. This may be partly due to the fact that the fungus was grown under non-inducing conditions. Previous studies have shown the secretion of fungal cell wall associated depolymerising enzymes by T. aggressivum in the presence of A. bisporus (Williams et al. 2003; Guthrie \& Castle 2006) and the production of these enzymes is considered to be indicative of mycoparasitic activity. However, in both studies the depolymerising enzymes were secreted into the extracellular space of T. aggressivum and so it may be that these proteins are insensitive to change or are present in relatively low abundance in the intracellular protein fraction.

Informational proteins are those that are involved in DNA duplication, transcription, and translation. These proteins are conserved between species and may be constitutively produced. Two transcription factors (no. 23, 25) and one protein which is a component of the ribosome (Table 2, spot A) were identified. One transcription factor (no. 23) has no known function or associated genes. The other, Hex 1 (no. 25) has homologues in all Trichoderma species (Table 1). Hex 1 is a major component of the woronin body complex as well as a transcription factor. Woronin bodies are present at the periphery of fungal hyphae where they prevent cellular leakage by blocking septal pores when hyphae are sheared (Lew 2011). Sequence analysis of Hex 1 from reveals that it has a peroxisome targeting signal and a high level of conservation between fungal species (Curach et al. 2004). In other Trichoderma species it has been shown to account for a significant amount of the total protein associated with the cell envelope (Lim et al. 2001) and is differentially produced in response to different carbon sources (Curach et al. 2004) and under biological control conditions (Marra et al. 2006) but no change was observed in Hex 1 abundance in either experimental treatment in this study.

There was a statistically significant down-regulation of the ribosome component $60 \mathrm{~S}$ acidic ribosomal protein $\mathrm{P0}$ (Table 2, spot A). Abundance of this protein was observed to change in both treatments. The $60 \mathrm{~S}$ acidic ribosomal protein $\mathrm{P} 0$ is a protein conserved in all eukaryotes which is the orthologue of the Escherichia coli protein L10 (Rich \& Steitz 1987). Differential expression and regulation of $60 \mathrm{~S}$ ribosomal protein $\mathrm{P} 0$ have been shown to be related to the cellular response to various stresses, including oxidative stress (Abramczyk et al. 2003; Maniratanachote et al. 2006).

Structural proteins are involved in cell stability, compartmentalization, and growth and they are typically constitutively produced (Klemsdal et al. 1996). No change was observed in the production of Rab GDP-dissociation inhibitor (no. 7) or Actin (no. 9) (Table 1), proteins involved in protein transport, and the cytoskeleton, respectively. A protein with an actin binding and depolymerising function was identified (Table 2, spot G) which was upregulated in response to both experimental treatments which indicates that there may be an alteration of cytoskeletal structure in T. aggressivum exposed to A. bisporus and mushroom compost.

The differentially produced proteins identified in this experiment can be divided into four groups: proteins increased in response to both treatments, proteins decreased in response to both treatments, proteins increased only in one treatment, and proteins increased in one treatment while reduced in the other.

Proteins increased in both treatments include: $60 \mathrm{~S}$ acidic ribosomal protein (Fig 2, spot A), Fe-Mn superoxide dismutase (Table 2, spot B), and an actin depolymerising enzyme from Trichoderma reesei (Table 2, spot G). For spots B and G the increase was greater in the mushroom compost treatment than the A. bisporus treatment.

The $60 \mathrm{~S}$ acidic ribosomal protein and $\mathrm{Fe}-\mathrm{Mn}$ superoxide dismutase are involved directly or indirectly in the oxidative stress response, and an increase in their production may result from components of $\mathrm{A}$. bisporus tissue and mushroom compost which exert oxidative stress on $\mathrm{T}$. aggressivum, or which induce changes in the metabolism of $\mathrm{T}$. aggressivum leading to an increase of intracellular reactive oxygen species.

Actin depolymerising enzyme can modify the structure of the actin cytoskeleton, which may lead to changes in hyphal growth. It has been previously shown that A. bisporus metabolites increase the rate of extension of T. aggressivum hyphae (Muthumeenakshi et al. 1998) and that and saprotrophic growth in mushroom compost is key to its survival strategy 
(Williams et al. 2003). The re-arrangement of the actin cytoskeleton may be an aspect of both of these behaviours.

Proteins decreased in both treatments: two proteins (Table 2, spots C and D) were down regulated in both experimental treatments. Protein $C$ was identified as spermine synthase and was only slightly reduced in the A. bisporus treatment with a more substantial decrease in abundance being observed in the mushroom compost treatment. Protein D was homologous with maintenance of telomere capping protein 2 from Zygosaccharomyces rouxii and was decreased in production to an approximately equal extent in both treatments.

Spermidine synthase catalyses the production of the polyamine spermidine from spermine (Pegg 1986). A reduction in the amount of spermidine synthase may relate to changes in the oxidative stress response as both spermidine and its precursor spermine are anti-oxidants which are also transcription factors for other genes involved in the degradation of reactive oxygen species (Kuznetsov et al. 2006; Tkachenko \& Fedotova 2007; Chattopadhyay et al. 2009).

Deletion of the gene encoding maintenance of telomere capping protein 2 in $\mathrm{Z}$. rouxii results in a phenotype more susceptible to telomere-shortening related cell-cycle arrests when exposed to heat stress (Addinall et al. 2008). The mechanism by which this protein protects the telomere cap is not known, but if it serves the same function in $T$. aggressivum then a decrease in the amount of this protein may lead to reduced cell longevity.

Proteins increased only in one treatment: copper-zinc superoxide dismutase (Table 2, spot F) was upregulated in the mushroom compost treatment, but not substantially altered in response to A. bisporus tissue. This protein serves a similar function as Fe-Mn superoxide dismutase. The production of this protein may indicate that oxidative stress resulting from exposure to mushroom compost is more significant than that experienced by T. aggressivum growing in medium containing A. bisporus tissue.

Proteins increased in one treatment while reduced in the other: guanylate kinase (Table 2, spot E) was increased twofold in the A. bisporus tissue treatment, but reduced by a similar amount in the mushroom compost treatment. This protein is essential in the production of the purine base guanine, and as such is vital to cell replication (Konrad 1992). The product of guanylate kinase, guanosine diphosphate, is also an intermediary in the cyclic GMP signalling pathway. In fungi the cyclic GMP pathway is part of processes such as conidiation, cell division (Eckstein 1988) and hyphal extension, and branching (Robson et al. 1991). It is difficult to assess what exact role guanylate kinase may be playing in this experiment but it is interesting that it is the only protein to have shown the opposite response to the mushroom compost and A. bisporus tissue treatments.

\section{Conclusion}

The results presented here give new insight into the proteome of Trichoderma aggressivum f. europaeum and its response to Agaricus bisporus and mushroom compost. Several proteins were shown to be differentially produced in the presence of A. bisporus tissue and/or Phase 3 mushroom compost with functions relating to stress tolerance, cell signalling, longevity, and structure. These functions may be part of the capability of $\mathrm{T}$. aggressivum to grow uninhibited in commercial mushroom composts, displacing A. bisporus, and ultimately reducing mushroom yields.

\section{Acknowledgement}

M. O'Brien was the recipient of a Walsh Fellowship awarded by Teagasc (The Irish Agriculture and Food Development Authority).

\section{R E F E R E N C E S}

Abramczyk O, Zień P, Zieliński R, Pilecki M, Hellman U, Szyszka R, 2003. The protein kinase $60 \mathrm{~S}$ is a free catalytic CK2 $\alpha^{\prime}$ subunit and forms an inactive complex with superoxide dismutase SOD1. Biochemical and Biophysical Research Communications 307: $31-40$.

Addinall SG, Downey M, Yu M, Zubko MK, Dewar J, Leake A, Hallinan J, et al., 2008. A genomewide suppressor and enhancer analysis of cdc13-1 reveals varied cellular processes influencing telomere capping in Saccharomyces cerevisiae. Genetics 180 (4): 2251-2266.

Candiano G, Bruschi M, Musante L, Santucci L, Ghiggeri GM, Carnemolla B, Orecchia P, Zardi L, Rigetti PG, 2004. Blue silver: a very sensitive colloidal Coomassie G-250 staining for proteome analysis. Electrophoresis 25: 1327-1333.

Chattopadhyay MK, Chen W, Poy G, Cam M, Stiles D, Tabor H, 2009. Microarray studies on the genes responsive to the addition of spermidine or spermine to a Saccharomyces cerevisiae spermidine synthase mutant. Yeast 29: 531-544.

Curach NC, Te'o VSJ, Gibbs MD, Bergquist PL, Nevalainen KMH, 2004. Isolation, characterization and expression of the hex1 gene from Trichoderma reesei. Gene 331: 133-140.

Eckstein KH, 1988. Evidence for cyclic GMP in the yeast Saccharomyces cerevisiae, and studies on its possible role in cell growth. Journal of Biosciences 13 (5-6): 386-396.

Fletcher JT, Gaze RH, 2008. Mushroom Pest and Disease Control - a color handbook. Elsevier Academic Press.

Fuente MEDL, Beyer DM, Rinker DL, 1998. First report of Trichoderma harzianum biotype Th4, on commercial button mushrooms in California. Plant Disease 82: 1404.

Guthrie JL, Castle AJ, 2006. Chitinase production during interaction of Trichoderma aggressivum and Agaricus bisporus. Canadian Journal of Microbiology 96: 961-967.

Hermosa MR, Grondona I, Monte E, 1999. Isolation of Trichoderma harzianum Th 2 from commercial mushroom compost in Spain. Plant Disease 83: 591.

Klemsdal SS, Hayes CK, Hjeljord L, Lorito M, Harman GE, Tronsmo A, 1996. Isolation and characterization of a CDNA from Trichoderma harzianum P1 encoding a 14-3-3 protein homolog. Gene 171: 123-127.

Konrad M, 1992. Cloning and expression of the essential gene for guanylate kinase from yeast. Journal of Biological Chemistry 267 (36): 25652-25655.

Kredics L, Jimenez LG, Naeimi S, Czifra D, Urbán P, Manczinger L, Vágvölgyi C, Hatvani L, 2010. A challenge to mushroom growers: the green mould disease of cultivated champignons. In: Méndez-Vilaz A (ed.), Current Research, Technology and Education Topics in Applied Microbiology and Microbial Biotechnology, pp. 295-305. 
Krupke OA, Castle AJ, Rinker DL, 2003. The North American mushroom competitor, Trichoderma aggressivum f. aggressivum, produces antifungal compounds in mushroom compost that inhibit mycelial growth of the commercial mushroom Agaricus bisporus. Mycological Research 102: 1467-1475.

Kubicek CP, Herrera-Estrella A, Seidl-Seiboth V, Martinez DA, Druzhinina IS, Thon M, Zeilinger S, et al., 2011. Comparative genome sequence analysis underscores mycoparasitism as the ancestral life style of Trichoderma. Genome Biology 12 (4): R40.

Kuznetsov VV, Radyukina NL, Shevyakova NI, 2006. Polyamines and stress: biological role, metabolism, and regulation. Russian Journal of Plant Physiology 53: 583-604.

Largeteau ML, Savoie J-M, 2010. Microbially induced diseases of Agaricus bisporus: biochemical mechanisms and impact on commercial mushroom production. Applied Microbiology and Biotechnology 86: 63-73.

Lew RR, 2011. How does a hypha grow? The biophysics of pressurized growth in fungi. Nature Reviews. Microbiology 9: 509-518.

Lim DB, Hains P, Walsh B, Bergquist P, Nevalainen H, 2001. Proteins associated with the cell envelope of Trichoderma reesei: a proteomic approach. Proteomics 1: 899-909.

Mamoun ML, Iapicco R, Savoie J-M, Olivier J-M, 2000a. Green mould disease in France: Trichoderma harzianum Th2 and other species causing damage on mushroom farms. In: Van Griensven LJLD (ed.), Science and Cultivation of Edible Fungi. Balkema, Rotterdam, pp. 625-632.

Mamoun ML, Savoie J-M, Olivier J-M, 2000b. Interactions between the pathogen Trichoderma harzianum Th2 and Agaricus bisporus in mushroom compost. Mycologia 92: 233-240.

Maniratanachote R, Minami K, Katoh M, Nakajima M, Yokoi T, 2006. Dephosphorylation of ribosomal protein P0 in response to troglitazone-induced cytotoxicity. Toxicology Letters 166: 189-199.

Marra R, Ambrosino P, Carbone V, Vinale F, Woo SL, Ruocco M, Ciliento R, Lanzuise S, Ferraioli S, et al., 2006. Study of the three-way interaction between Trichoderma atroviride, plant and fungal pathogens by using a proteomic approach. Current Genetics 50: 307-321.

Martinez D, Berka RM, Henrissat B, Saloheimo M, Arvas M, Baker SE, Chapman J, et al., 2008. Genome sequencing and analysis of the biomass-degrading fungus Trichoderma reese (syn. Hypocrea jecorina). Nature Biotechnology 26 (5): 553-560.

Mumpuni A, Sharma HSS, Brown AE, 1998. Effect of metabolites produced by Trichoderma harzianum biotypes and Agaricus bisporus on their respective growth radii in culture. Applied and Environmental Microbiology 64: 5053-5056.

Muthumeenakshi S, Mills PR, Brown AE, Seaby DA, 1994. Intraspecific molecular variation among Trichoderma harzianum isolates colonizing mushroom compost in the British Isles. Microbiology 140 (4): 769-777.
Muthumeenakshi S, Brown AE, Mills PR, 1998. Genetic comparison of the aggressive weed mould strains of Trichoderma harzianum from mushroom compost in North America and the British Isles. Plant Pathology 102: 385-390.

Neuhoff V, Arold N, Taube D, Ehrhardt W, 1988. Improved staining of proteins in polyacrylamide gels including isoelectric focusing gels with clear background at nanogram sensitivity using Coomassie Brilliant Blue G-250 and R-250. Electrophoresis 9: $255-262$.

Pegg AE, 1986. Recent advances in the biochemistry of polyamines in eukaryotes. The Biochemical Journal 234 (2): 249-262.

Rich BE, Steitz JA, 1987. Human acidic ribosomal phosphoproteins PO, P1, and P2: analysis of cDNA clones, in vitro synthesis, and assembly. Molecular and Cellular Biology 7: 4065-4074.

Robson GD, Wiebe MG, Trinci AP, 1991. Exogenous cAMP and cGMP modulate branching in Fusarium graminearum. Journal of General Microbiology 137 (4): 963-969.

Samuels GJ, Dodd SL, Gams W, Castlebury LA, Petrini O, 2002. Trichoderma species associated with the green mold epidemic of commercially grown Agaricus bisporus. Mycologia 94: 147-170.

Savoie J-M, Iapicco R, Mamoun ML, 2001a. Factors influencing the competitive saprophytic ability of Trichoderma harzianum Th2 in mushroom (Agaricus bisporus) compost. Mycological Research 105: 1348-1356.

Savoie J-M, Mata G, Mamoun ML, 2001b. Variability in brown line formation and extracellular laccase production during interaction between white-rot basidiomycetes and Trichoderma harzianum biotype Th2. Mycologia 93: 243-248.

Seaby DA, 1987. Infection of mushroom compost by Trichoderma species. Mushroom Journal 179: 355-361.

Shevchenko A, Tomas H, Havlis J, Olsen JV, Mann M, 2006. In-gel digestion for mass spectrometric characterization of proteins and proteomes. Nature Protocols 6: 2856-2860.

Sobieralski K, Siwulski M, Frużyńska-Jóźwiak D, Błaszczyk L, SasGolak I, Jasińska A, 2010. Impact of infections with two Trichoderma aggressivum f. europaeum isolates on the yielding of some wild strains of Agaricus bisporus (Lange) Imbach. Journal of Plant Protection Research 50: 501-504.

Tkachenko AG, Fedotova MV, 2007. Dependence of protective functions of Escherichia coli polyamines on strength of stress caused by superoxide radicals. Biochemistry (Moscow) 72: 109-116.

Viterbo A, Ramot O, Chemin L, Chet I, 2002. Significance of lytic enzymes from Trichoderma spp. in the biocontrol of fungal plant pathogens. Antonie van Leeuwenhoek 82: 549-556.

Williams J, Clarkson JM, Mills PR, Cooper RM, 2003. Saprotrophic and mycoparasitic components of aggressiveness of Trichoderma harzianum groups toward the commercial mushroom Agaricus bisporus. Applied and Environmental Microbiology 69: 4192-4199. 